\title{
THE DIFFERENCE OF MANAGERIAL APPROACH IN MORE OR LESS DESIGN-ORIENTED COMPANIES
}

\author{
Sanja Rocco* \\ Aleksandra Selinšek $k^{* *}$
}

Received: 27. 6. 2019

Preliminary communication

Accepted: 12. 5. 2020

UDC 005.342

DOI https://doi.org/10.30924/mjcmi.25.1.11

\begin{abstract}
While the market orientation of companies has been thoroughly analysed, a review of the marketing literature indicates that there is significantly less research on Design Orientation, and especially on their relationship. This paper analyzes the variables of Design and Market Orientation on the basis of existing models and develops the measurement instrument for future research. The study also investigates the impact of managerial approach on the exploitation of design resources in the company. Two hypotheses are developed: the first on the DOMO relationship, acknowledging the multiple dimensions of Design Orientation and the second on the difference in managerial approach between more and less design-oriented companies. The first, qualitative stage of the research served to re-examine the research constructs and variables, while an Internet survey was used in the second, quantitative stage, among managers and CEOs from Croatian companies. The design dimensions in our final model represented intermediaries between Market Orientation, managerial approach, and market outcomes. Results confirm that managers in non-design oriented companies differ from those in designoriented companies by perceived design value. Managers' and CEOs' awareness of design, its value and potentials, are of great importance for design implementation and Design Orientation
\end{abstract}

of a company as a whole, especially in SMEs. Managerial approach, according to results, has a direct effect on Design Orientation, but it also influences Market Orientation, both directly and indirectly, as well as business success. Findings of this study can have implications for scholars, as well as for managers in practice, especially in emerging economies, which lack research in Design Orientation. Future research should be expanded to other countries in the region.

Key words: design management, design orientation, market orientation, emerging markets, managerial approach

\section{INTRODUCTION}

In marketing literature Market Orientation (MO) is a well researched concept. Most of the results show a positive effect of MO on a company's performance (Narver and Slater, 1990; Jaworski et al., 1993; Kohli et al., 1993; Snoj et al., 2007; Bodlaj 2010). Nowadays, it is important to satisfy customers, creating added value beyond functional benefits in terms of emotional and social benefits (Pisnik et al., 2016). Considering this fact, companies

\footnotetext{
Sanja Rocco, MSc, Senior lecturer (Corresponding author), Zagreb School of Business, Ulica grada Vukovara 68, Croatia, Phone: 385 (0)91 4445 814, E-mail: sanja.rocco@pvzg.hr

** Aleksandra Selinšek, PhD, Associate professor, University of Maribor, Faculty of Business and Economics,Slovenia, aE-mail: aleksandra.selinsek1@um.si
} 


\section{Journal of Contemporary Management Issues}

should not only be market oriented, but they also have to be design oriented, while focusing on the customers (Gummesson, 1991; Moll et al., 2007; Coley et al., 2010; Venkatesh et al., 2012; Rocco, Selinšek, 2019).

Design is still commonly percieved as a means of beautification of products, in order to attract more customers and sell at a higher price. According to Best (2006), design not only has a substantial function in defining our environment and generating new products, but also in defining services and processes as a response to various market conditions and opportunities. The valuation of design and its function in the process of innovation, whether in terms of characteristics of products, or in terms of the process of production, has still been neglected by most managers (Verizer and B. de Mozota, 2005; B. de Mozota, 2009).

Nevertheless, some marketing scholars (e.g. Gummesson, 1991; Jaworski and Kohli, 1993; Coley et al., 2010), and also design scholars (Moll et al., 2007; Venkatesh et al., 2012) emphasize the importance of design in product and service innovation, as well as at the strategic level of the organization.

There is evidence that companies, which manage design, in order to use their resources better, also achieve better business results than those which do not. The emphasis, therefore, is not on investing in design by chance, but on a controlled design management process that delivers good results (Chiva and Allegre, 2009). The main difficulty in implementing design and achieving collaboration in innovation projects is the education of managers. That is why managers from non-design oriented companies are not familiar with design benefits, or interested in design. As shown by previous research, design has to be incorporated into all units of an organization in order to be successful, (Borja de Mozota, 2003a; Best, 2010).

Slater and Narver (2000) believe that MO is positively related to business profitability. According to their research MO, as a constituent of business culture, seems to be a more important factor than entrepreneurial orientation. Grinstein (2008) believes that, if guided by a system of beliefs, market orientation can be implemented successfully, and is related positively to a number of strategic orientations. Existing empirical research, adopting both responsive MO, which deals with the stated needs of customers, and proactive MO, which focuses on their latent needs, is still very limited. It focuses on on success of new-to-the market products (e.g. Narver et al., 2004; Atuahene-Gima, 1995) or on results of businesses (e.g. Voola and O'Cass, 2010), and is conducted mostly in non-European countries (Bodlaj, 2010; Rocco, Selinšek, 2019).

In Croatia, one can find an extensive history of MO research from different aspects: $\mathrm{MO}$ and employee involvement in companies (Martin, Martin and Grbac, 1998); MO and supplier relationships (Martin, Grbac, 2003), the export MO of Croatian SMEs (Miočević, CrnjakKaranović, 2012), MO and innovation research using the case study method (Božić, Ozretić-Došen, 2015); MO in the non-profit sector, such as higher education (Pavičić, Alfirević, Mihanović, 2008; Barilović, Leko Šimić, Štimac, 2014), or MO of internationally active and non-active institutions in the Arts and Culture (Gluić, Mihanović, 2016).

We have a pretty comparable situation with Design Orientation (DO). Design Orientation uses design as a transformative process in all of the company, and is seen as an organizational model (Venkatesh et al., 
2012). The confirmative relation between design investment and businesses performance has been shown in different studies. A document "The Economic Effects of Design", published by the Danish Design Center (DDC, 2004), as a result of a research on the national level, confirmed the correlation between the use of design and the economic performance of companies. A series of researches on the topic was undertaken by the British Design Council - The Design Council National Survey published in 2004 (DC 2004, Cox, 2005), The Value of Design Factfinder (DC 2012) and the Design Council study "The Design Economy 2018. The State of Design in the UK" (DC, 2018). The main results show that fast-growing companies are almost six times more presumably to implement design as an integral part of the company. Also, on average, companies in the UK with investments in design generate significantly better long-term profit than those that do not. Studies about the effect of design on such things as consumer satisfaction, new product or service development, and innovation or business performance exist as well.

The way design is managed as well as integrated within other departments is as important as the value of investing in design resources. Whether or not the two functions, design and marketing, should be integrated is an ongoing discussion, and opinions remain divided despite the literature surrounding the marketing-design relationship (Rocco, Pisnik, 2016a). Results of our previous study (Rocco, Selinšek, 2019) show the positive relationship between Design Orientation and Market Orientation. Furthermore, results also confirm that customer orientation and strategic marketing are positevely related to Design Orientation. In this paper we are going a step deeper and raise two more research questions, focused on Design Orientation: first, do all dimensions of Design Orientation, which is a multidimensional concept, relate to Market Orientation and second, what is the difference between managers who have high awareness of the importance of design and those with lower awareness of it. Therefore, the novelty of the present paper is the research on managerial approach toward design orientation. Investigating complex relations between Design Orientation and Market Orientation in Croatian enterprises, and especially the influence of managers on their design orientation, have been the main purposes of this paper, because these relationships have not yet been analysed.

\section{THEORETICAL BACKGROUND}

\subsection{Innovation by design}

Through design history - from the era of the industrial revolution and the beginning of mass production - the focus of design has shifted from the object, i.e. producing the physical products, to the process - the human-centered way of production, or applying the design methodology in solving problems: From the initial ideas to the complex strategic decisions (Borja de Mozota, 2003a). By using design, we not only create products and services, but also complex systems, with a special focus on the user experience. Leading companies create value using design to transform their businesses, shifting the focus of their innovation from engineering to designing. Design thinking is the basis of an efficient development strategy that brings about positive organizational change, and is a priority for an increasing number of CEOs. In this study, we understand design as a planned activity in order to create an object, a product, a process or a system. 


\section{Journal of Contemporary Management Issues}

A number of scholars point out the contribution of design and its methods to innovation. Many researchers have emphasized design, its creative methods and way of thinking as a means to increase a company's innovation capacity (Ulrich \& Eppinger, 2000; Veryzer and Borja de Mozota, 2005; Beverland \& Farrell, 2007). Design is undersood to have a clear focus on users and customers, as well as on applying a creative way of thinking in finding new solutions (Kelley, 2000; von Stamm, 2003).

Also, research in managing design efficiently indicates that design improves innovation, whether it is technological or nontechnological (Borja de Mozota, 2003b; Von Stamm, 2003 in Rocco, Selinšek, 2019). Design obtains significance as a driver for innovation, resulting in new business models: design strategy, managing design and applied design thinking (Quartz and Co, 2011). Design connects creativity with innovation, and forms ideas in a way that they become an attractive offer for consumers (Cox, 2005). The three-dimensional taxonomy of design as an element of innovation (Norman, 2004) provides a suitable structure for categorizing the essence of design since it successfully apprehends the classification elements of other scholars (Dreyfuss 1967; Kotler and Rath 1984; Ulrich and Eppinger 2003; Stuart and Tax, 2004): Visceral design appeals to the senses, Behavioral design is about usability and performance, while Reflective design deals with the transmission of the message and the cultural meaning of the product or service.

We should mention the Action Plan for Design-Driven Innovation (EC, 2013), developed as a result of the Europe 2020 Growth Strategy, which recognizes design potentials in the innovation process. There were also some other design-designated initiatives, yet most of them are concentrated in regions with strong creative industries and economies. As part of the Design EntrepreneurSHIP project, a qualitative research was conducted aiming to improve the competitiveness of SMEs from the region of South Baltic which were recognized as being less competitive. The use of design is rarely implemented beyond the tactical level in SMEs of the region. The research problem was a rather neglected focus on innovation development in SMEs and the emphases on the importance of integrating design from tactical to strategy level (Gerlitz, 2016). If we look at the situation in Croatia, improvements in innovation performance largely depend on innovation activities in SMEs, since they dominate the country's business structure (Božić and Mohnen, 2016).

\subsection{Managing design}

The concept of design management is complex and subject to various interpretations relating to managing design in the company, but also to the application of creative design methods in management generally. The basic task of design management is to detect the creative forces inside the company, and to use them as a strategic advantage.

The first definition of design management, according to Acklin and Fust (2014), was coined by Michael Farr $(1965,38)$ as „the function of defining a design problem, finding the most suitable designer, and making it possible for him to solve it on time and within a budget". Meanwhile, design management has been accepted as a tool that companies can use to incorporate design into their business processes, starting from the strategic, to the operational level. This evolution has fully integrated design 
into the "agenda" of management that is responsible for improving customer experiences (Cooper \& Press, 1995). Design and its management have, more recently, been recognized as a driving force of organizational change (Junginger, 2008, 2009). „Design Management includes the ongoing processes, business decisions, and strategies that enable them to innovate and create effectively-designed products, services, communications, environments and brands that enhance our quality of life and provide organizational success “. At a deeper level, Design Management is seeking to connect design with innovation, technology, management and consumer needs, in order to ensure and strenghten competitiveness through different variables - economic, social, cultural and environmental. The scope of design management, which plays a key role in differentiating and initiating positive organizational change, ranges from the operational management of corporate design functions and resources, to strategic design planning throughout the organization. Implementing design management in business management requires the use of design methodology in the decision making process $^{1}$.

An exploration undertaken in 2009 presents an analysis of design management implemented by European companies, which applied the DM Staircase model from Kootstra (2009). This method should enable European companies to accomplish their capabilities of managing design, allowing them to increase its effective use and improve their competitiveness and business success. Following the investigation, the DM competences of European businesses were ranked into four categories, ranging from undeveloped (no $\mathrm{DM}$ ) to fully mature (DM as culture), in which design was managed strategically.

\footnotetext{
1 https://www.dmi.org/page/What_is_Design_Manag
}

Five factors, which influence the successful design implementation, further define these four levels of DM. Multiple choice questions explained each of these factors. Subsequently, a large scale study was carried out amongst 605 European businesses to test the DM Staircase model. As a conclusion of the EU businesses' research results, introduced in Kootstra's "The Incorporation of Design Management in Today`s Business Practices" report (2009), Design Management performance can be measured from different perspectives, both financial and nonfinancial - the financial measures are the company turnover, the product development and implementation costs and financial success in the market, while the nonfinancial measures are customer satisfaction through added value and loyalty, creativity of products and services, and innovation.

Four DM methods, introduced by Acklin and Fust (2014), differ in terms of their strategic contribution to the company and its orientation: a simple use, integral, dynamic, and entrepreneurial. The fourth, entrepreneurial mode, explores the relations between entrepreneurship, design and its management. Managing design can take a more active position in companies when it comes to entrepreneurial topics - as a driver of creativity and innovation, but also in exploiting the new opportunities.

\section{THE HYPOTHESIS DEVELOPMENT BACKGROUND}

After studying the existing literature, an initial model of relations between DO and MO was created, based on previous models (see Figure 1). The concept of this model has previously been presented at the ESD International Conference in Barcelona 


\section{Journal of Contemporary Management Issues}

(Rocco, Pisnik, 2016a). This paper examines the relationships between different dimensions of Design Orientation and Market Orientation, as well as managerial perception of design in more or less design oriented companies, which is only a part of the broader reserach.

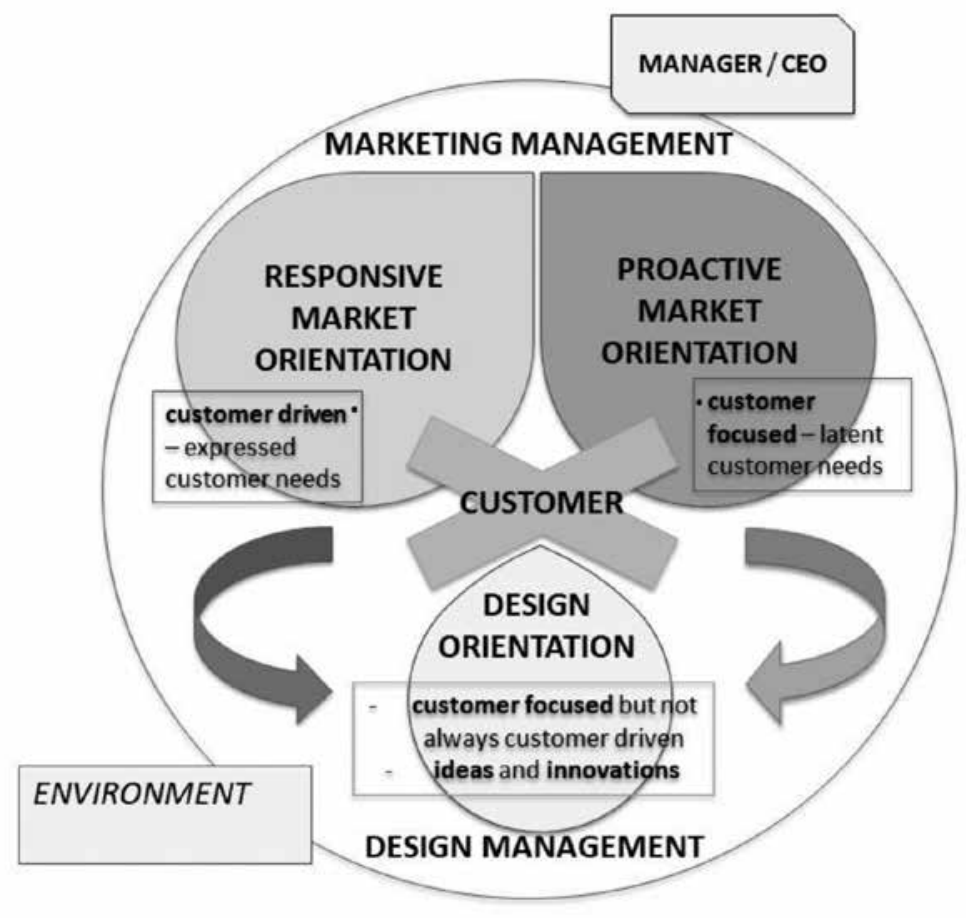

Figure 1. The initial conceptual model

Source: Authors

Design is a complex and multidimensional construct. Bayazit (2004) claims that design is a holistic term which investigates and integrates diverse forms of knowldge. It includes functional and technological systems, as well as empathy with human needs, the expression of esthetics, usable forms and solutions. We accept the definition provided by various scholars and researchers that Design Orientation supports a strategic management technique grounded on the selection of design resources as an instrument of competitiveness (Gorb 1990; Borja de Mozota, 2003b, 2009; Best 2006; Moll et al., 2007; Von Stamm, 2008;
Brown, 2008; Kootstra 2009; Venkatesh et al. 2012; Rae 2013; European Commission 2013; Design Council 2015, 2018; Buchanan 2015, DMI 2015; Rau 2017). Therefore, we propose the first hypothesis:

H1. All dimensions of Design Orientation (DO) are related to Market Orientation (MO).

Recently, a huge interest has been shown in the creative capabilities, possessed by designers from fields and disciplines outside the traditional realm of design, which is highlighted by the discussion around the concept of design thinking. 
Interest has been growing steadily since the introduction of the concept to the general public by Tim Brown in 2008, and shortly after by Roger Martin, with numerous books and accounts of utilization of Design thinking in different contexts. (Ekman et al, eds, 2017, 86). The tools and philosophies behind creative way of thinking are perceived as a useful methodology in the process of management, from the strategic to the operational level. The design thinking method combines convergent and divergent thinking, as well as the intuitive, rational, and analytical ones. Design thinking is a business model which uses design methods to resolve general problems (Brown, 2008; Johansson et al., 2008; Stevens et al., 2008; Martin, 2009; Borja de Mozota, 2011; Quartz + Co, 2011).

Managers interested in design thinking as an innovative decision-making method should see design as source of knowledge and a valuable potential, and should also integrate design theories into the organizational theories (Borja de Mozota \& Peinado, 2013). Managers have a key role in design implementation and the level of its integration in various company units. Therefore, we propose the second hypothesis of this paper:

H2. Managers in non-design oriented companies differ from managers in designoriented companies by perceived design values.

\section{RESEARCH METHODOLOGY}

The research was conducted by using qualitative and quantitative methods. A preliminary list of measurement variables was selected initially from relevant previous research, dealing with $\mathrm{MO}$ and $\mathrm{DO}$. The first, qualitative stage of the research was conducted during 2016. A sample of typical representatives for qualitative research - 5 managers and 5 designers, was based on the researchers' judgment. The focus was on the topic of Design Orientation, and it served as the basis for improving the questions about DO for the final questionnaire, used in the quantitative stage.

The quantitative stage of the research was conducted through an online survey, among managers and CEOs from different Croatian industries. In order to avoid micro-enterprises, questionnaire had to be completed by the companies that employ at least 3 people. The measurement instrument consisted of measurement scales for assessing the levels of Market Orientation, Design Orientation, managerial approach and business success. Most of the statements in the questionnaire used the Likert scale (ranging from 1 to 5). For measuring Market Orientation, 19 items were adopted from Lafferty and Hult (2001) and Narver et al. (2004). The Design Orientation scale was adopted from Borja de Mozota (2003b) and was measured by 13 items. For design implementation, a three item scale was adopted from the Design Management Institute (DMI, 2015). For measuring the managerial approach, five items were used from the Centre for Design Innovation Ireland (2007), and additional six criteria for the use of creative methods in the process of decision-making were evaluated on the scale. For the measurement of company performance, ten items were used. Respondents had to evaluate the overall performance of their business in the last 3 years on the scale from 1 - lowest score to 5 - highest score. Additional nine performance criteria were evaluated (performance rate against competition, growth and profitability dimensions, demand for products/ services). The final section of the questionnaire included additional questions with 


\section{Journal of Contemporary Management Issues}

general data about the respondents and their companies. Clarity of the questions as well as the measuring system were tested with a pool of academics, namely eight experts from the fields of marketing and market research, and one from the design field, preceding the execution of the qualitative research.

\subsection{Results of the preliminary research}

A selection of five designers, as well as five selected top managers were interviewed to gain a better insight into where their opinions differ. Concerning the sample of five managers, four of them were managing different departments, while one was also a CEO. Their companies were from different industries; three of them were SMEs and two were large ones. Concerning the sample of selected designers, one was a freelance-designer, three were from small design studios, and one was a creative director of a large advertising agency. Most of them were experienced. They covered different design fields, from visual communication, to interior design. Most of the designers stated that marketing managers or CEOs were persons in charge of design in their company.

According to the main topics prepared for the interviews, respondents from both goups, managers, as well as designers, were first asked to determine the meaning of design in their own words. They also needed to select design elements, according to their importance for successful business results. The topic of Market Orientation was also included in the interview, as well as the evaluation of the design environment in Croatia. Both groups of respondents emphasized elements of Design Orientation concern for the consumers, and the use of creativity in offering added value of products as important. However, while managers mostly perceive design implementation as an opportunity to make more profit, designers underline the significance of applying design at different levels of a company. Problems in communication between managers and designers were also one of the topics, and, while managers mentioned mostly a dissimilar perspective on design tasks and priorities, as well as unprofessionalism, designers were facing disagreement with managers on the issues of imprecise design briefs, short deadlines and lack of knowledge about the design processes.

Although managers specified that they use design widely throughout their company, from visual identity to strategy development, designers estimated that most of their clients apply design only in certain areas such as visual communication, promotional activities or development of brands and new products. Both groups of respondents agree on assessing the state of design in Croatia as mediocre, emphasizing the unfriendly environment for design implementation and ignorance of strategic design management at the national level (Rocco, Pisnik, 2016b).

While the previous study (Rocco, Selinšek 2019) focused on the market orientation perspective, in this article we look deeper into the DO-MO relationship concerning the multiple dimensions of Design Orientation. The focus of this paper is also to examine different attitudes of managers and their influence on the exploitation of design resources.

\section{FINAL RESULTS AND HYPOTHESIS TESTING}

An e-mail database was compiled for various profiles of managers in Croatian companies from reliable sources of 
Croatian State Institutions (Ministry of Entrepreneurship and Crafts, the Croatian Chamber of Economy, and the Croatian Agency for Development of SMEs). The final list consisted of more than 2,000 e-mail contacts. A motivating introductory email message was sent to these contacts together with an explanation of the research, and a link to an electronic questionnaire.

A definition of design, according to the British Design Council, was added in the questionnaire, as advised by several experts from the pretesting phase:

In this research, we look at design very broadly, as a thoughtful creative approach to solving problems that results in innovative solutions, and can be applied to products, services, internal communications, work processes and environments, as well as external communication and, ultimately, to a company's strategy.

The online questionnaire had thirty questions, twenty-one of which concerned the main topics: MO, DO, managerial style, coordination between different functions, company results and Croatian design legisation. The Likert value scale (from 1 to 5 points) was used in most of them. General questions about the examinees and their companies were at the end. Scales were previously verified by using a pretesting Exploratory Factor Analysis (EFA) for construct validity, and results confirmed that the proposed scales for measuring DO and MO were reliable.

\subsection{Description of the sample}

The survey was conducted in 2017. From the original mailing-list, almost 400 emails were undelivered, and the new message with a link was sent in mid-September to those who did not respond. 233 clicks were generated from the total number of sent emails (clickthrough rate: 13,04\%). It should be noted that many respondents started answering the questionnaire, but gave up before completing it. There was a total of 143 complete questionnaires, which gave a 61 percent response. Of these, 112 respondents were eligible for the research from companies with more than 3 persons employed, which represents the return rate of 78\% (Rocco, Selinšek, 2019).

The strucuture of companies from the research sample was as follows: $40 \%$ in the product industries, $33 \%$ in the service industries and $27 \%$ in the combined industries. The 112 respondents came from companies of different sizes, namely 27 between 3 and 10 employees, 38 between 11 and 50, 17 between 51 and 100, 7 between 101 and 200 and 23 with over 201 employees. If we apply the SMEs definition of the European Commission (EC, 2003), the ratio of approx. $80 \%$ of SMEs and $20 \%$ of large companies is present in our sample, which is acceptable concerning the structure of the Croatian entrepreneurs.

The structure of the respondents was as follows: $42 \%$ women and $58 \%$ men. Concerning the position in the company, $60,7 \%$ were managers and 39\% CEOs. Regarding age, $42,9 \%$ of respondents were between 40 and 49 years of age, while, at the second position, 22,3\% were between 30 and 39 , as well as between 50 and 59 . Concerning the education, most of the respondents were graduates $(47,3 \%)$, followed by Masters of Science (15.2\%) and those with the undergraduate degree were in the third place.

\subsection{Testing the hypothesis $\mathrm{H} 1$}

With regard to the verification of reliability and validity in our study, the following methods were used: Exploratory Factor Analysis, reliability analysis, convergent 


\section{Journal of Contemporary Management Issues}

and discriminant validity. The purpose of these tests was to evaluate the dimensionality of the measurement scales. EFA of variables for $\mathrm{MO}$ and $\mathrm{DO}$ on the final sample $(\mathrm{N}=112)$ was the first step.

The K-M-O measure and Bartlett's test were appropriate $(0,89 ; \mathrm{p}<0,001)$. EFA results identified a two-factor solution for Market Orientation, which explains 30,9\% of total variance, and a three-factor solution for Design Orientation, which, explains $32,7 \%$ of total variance.

The importance of design from the managers' perspective was shown in the question about the role design plays in their company. More than $80 \%$ of managers rated design as important, namely $21 \%$ think that design plays an important role, $27 \%$ stated that design is extremely important, while $30 \%$ estimate design even as a strategic tool. However, for $18.8 \%$ it plays a limited role, while for only $1 \%$ of managers, design has no importance.

In order to verify the hypothesis of the relations among three dimensions of Design and Market Orientation, PLS SEM analysis was conducted with the initial model of influences (see Fig.2) .

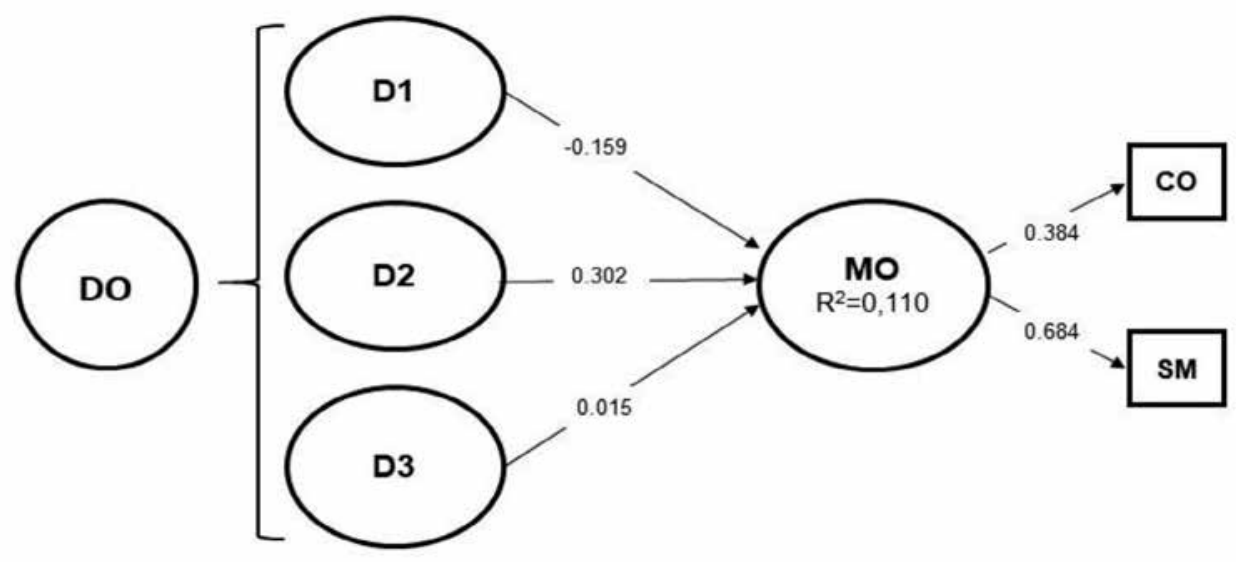

Figure 2. The initial PLS SEM model of a relationship between DO and MO

Source: Authors

Note: $\mathrm{DO}=$ Design Orientation: $\mathrm{D} 1=$ design as a competitive market advantage, $\mathrm{D} 2=$ the role of design in communication and management, $\mathrm{D} 3=$ design implementation, $\mathrm{MO}=$ Market Orientation: $\mathrm{CO}=$ Customer Orientation, $\mathrm{SM}=$ Strategic Marketing

Two factors construct Market Orientation and, according to their common attributes, they are named as Strategic Marketing $(\alpha=0.831)$, with five indicators and Customer Orientation $(\alpha=0.946)$, with fourteen indicators. Furthermore, the Design Orientation construct is composed of three factors: 'Design as a competitive advantage' $(\alpha=0.780)$ with three indicators, the 'Role of design in communication and management' $(\alpha=0.933)$ with 13 indicators, and the 'Level of design implementation' $(\alpha=0.811)$ with three indicators. Cronbach's alphas are appropriate (above 0.7 ).

The Design Orientation factors explain $11 \%$ of the variance of Market Orientation, with the highest path coefficient 0.302 for 
the factor 'Role of design in communication and management', while the other two factors have very weak ('Design implementation') or even negative ('Design as a competitive advantage') coefficient. The results reflect the realistic situation on the Croatian market in a certain way, where design is still not recognized as a strategic tool for achieving competitiveness.
The SRMR in the equation model is 0,045 , which is acceptable (e.g. Yong \& Pearce, 2013; Henseler et al., 2015) and the model describes the data and relationships between variables and factors well.The values of the HTMT ratio for the determination of discriminant validity are presented in Table 1.

Table 1. HTMT values

\begin{tabular}{|c|c|c|c|}
\hline $\begin{array}{l}\text { Design } \\
\text { implementation } \\
\text { (D1) }\end{array}$ & $\begin{array}{l}\text { Design as a } \\
\text { competitive market } \\
\text { advantage (D2) }\end{array}$ & $\begin{array}{l}\text { The role of design } \\
\text { in communication } \\
\text { and management } \\
\text { (D3) }\end{array}$ & $\begin{array}{l}\text { Market } \\
\text { Orientation } \\
\text { (MO) }\end{array}$ \\
\hline
\end{tabular}

\begin{tabular}{|c|c|c|c|}
\hline \multicolumn{4}{|l|}{ Design implementation } \\
\hline $\begin{array}{l}\text { Design as a competitive } \\
\text { market advantage }\end{array}$ & 0.219 & & \\
\hline $\begin{array}{l}\text { The role of design in } \\
\text { communication and } \\
\text { management }\end{array}$ & 0.112 & 0.070 & \\
\hline Market Orientation & 0.174 & 0.140 & 0.303 \\
\hline
\end{tabular}

Source: Research results

HTMT values do not exceed 0.9 for all the factors of Design and Market Orientation, which confirms the fact that there are sufficient differences in constructs to be acceptable as separate entities i.e. separate factors. Hypothesis H1, which refers to the relationship of all dimensions of Design Orientation with Market Orientation, is supported by the results of the analysis. However, the influence of different Design Orientation factors on Market Orientation varies.

\subsection{Testing the hypothesis $\mathbf{H} 2$}

The mean values for groups of more DO and less DO companies were calculated for all three factors of Design Orientation: the competitive advantage of the design factor, the role of design factor and the level of design implementation factor, and then tested, according to each variable of managerial approach.
The variables of managerial approach were tested according to the two groups with Levene's Test and t-test. Results show that Design as a competitive advantage factor was related to discussion and comparison with competition, understanding employee contribution, and the importance of design and innovation. Companies with a higher competitive factor of design score have, on average, statistically significantly more results on the above-mentioned management approach issues.

The role of design factor was associated with all the variables/questions, related to the company's managerial approach. Companies with a more prominent role of design also have statistically significantly higher results on all questions about managerial approach and skills.

The level of design implementation factor was linked to certain variables of 
managerial approach, such as comparison with competitors, understanding of employees' contribution, and importance of design. It should be noted that even the variables/ questions for which statistical significance is not at the level of $\mathrm{p}<0.05$ are statistically significant at the level of $10 \%(\mathrm{p}<0.10)$. The managerial approach was also tested against perceived design value.

Table 2. Percieved design value by managers

\begin{tabular}{|c|c|c|c|c|c|c|c|}
\hline Variables of design & $\begin{array}{l}\text { Design } \\
\text { Orientation } \\
\text { DO total } \\
\end{array}$ & $\mathbf{N}$ & $\begin{array}{l}\text { Mean } \\
\text { value }\end{array}$ & $\begin{array}{l}\text { Std. } \\
\text { Deviation }\end{array}$ & $\mathrm{t}$ & Df & Sig. \\
\hline \multirow{2}{*}{$\begin{array}{l}\text { Design creates a } \\
\text { competitive advantage. }\end{array}$} & Less DO & 55 & 3,91 & ,646 & \multirow{2}{*}{$-8,562$} & \multirow{2}{*}{95} &, 000 \\
\hline & More DO & 57 & 4,81 & ,441 & & & \\
\hline \multirow{2}{*}{$\begin{array}{l}\text { Design contributes } \\
\text { significantly to benefits } \\
\text { perceived by consumers. }\end{array}$} & Less DO & 55 & 3,69 & 879 & \multirow{2}{*}{$-6,743$} & \multirow{2}{*}{91} &, 000 \\
\hline & More DO & 57 & 4,63 &, 555 & & & \\
\hline \multirow{2}{*}{$\begin{array}{l}\text { Design changes the } \\
\text { spirit of the firm, } \\
\text { which becomes more } \\
\text { innovative. }\end{array}$} & Less DO & 55 & 3,53 & ,979 & \multirow[b]{2}{*}{$-5,559$} & \multirow[b]{2}{*}{94} &, 000 \\
\hline & More DO & 57 & 4,40 & ,651 & & & \\
\hline \multirow{2}{*}{$\begin{array}{l}\text { Design allows a } \\
\text { company to sell at a } \\
\text { higher price. }\end{array}$} & Less DO & 55 & 3,58 & 875 & \multirow{2}{*}{$-9,289$} & \multirow[b]{2}{*}{76} &, 000 \\
\hline & More DO & 57 & 4,79 & ,411 & & & \\
\hline \multirow{2}{*}{$\begin{array}{l}\text { Design improves } \\
\text { coordination between } \\
\text { marketing and } \mathrm{R} \& \mathrm{D} \\
\text { functions. }\end{array}$} & Less DO & 55 & 2,78 & 854 & \multirow[b]{2}{*}{$-7,049$} & \multirow[b]{2}{*}{110} &, 000 \\
\hline & More DO & 57 & 3,89 &, 817 & & & \\
\hline \multirow{2}{*}{$\begin{array}{l}\text { Design is a know-how } \\
\text { that transforms the } \\
\text { processes. }\end{array}$} & Less DO & 55 & 3,04 & 860 & \multirow{2}{*}{$-6,759$} & \multirow{2}{*}{110} &, 000 \\
\hline & More DO & 57 & 4,09 &, 786 & & & \\
\hline \multirow{2}{*}{$\begin{array}{l}\text { Design gives access to a } \\
\text { wide variety of markets. }\end{array}$} & Less DO & 55 & 3,55 & 899 & \multirow{2}{*}{$-5,801$} & \multirow{2}{*}{110} &, 000 \\
\hline & More DO & 57 & 4,40 & ,651 & & & \\
\hline \multirow{2}{*}{$\begin{array}{l}\text { Design improves } \\
\text { coordination between } \\
\text { production and } \\
\text { marketing. }\end{array}$} & Less DO & 55 & 3,16 & 996 & \multirow[b]{2}{*}{$-3,744$} & \multirow[b]{2}{*}{110} &, 000 \\
\hline & More DO & 57 & 3,84 & ,922 & & & \\
\hline \multirow{2}{*}{$\begin{array}{l}\text { Design develops } \\
\text { project management of } \\
\text { innovation. }\end{array}$} & Less DO & 55 & 3,16 & ,918 & \multirow{2}{*}{$-5,364$} & \multirow{2}{*}{110} &, 000 \\
\hline & More DO & 57 & 4,11 & ,939 & & & \\
\hline \multirow{2}{*}{$\begin{array}{l}\text { Design creates new } \\
\text { niche markets. }\end{array}$} & Less DO & 55 & 3,40 & 894 & \multirow{2}{*}{$-7,431$} & \multirow{2}{*}{94} &, 000 \\
\hline & More DO & 57 & 4,47 & 601 & & & \\
\hline \multirow{2}{*}{$\begin{array}{l}\text { Design improves } \\
\text { the circulation of } \\
\text { information. }\end{array}$} & Less DO & 55 & 2,93 & 1,052 & \multirow{2}{*}{$-6,180$} & \multirow{2}{*}{98} &, 000 \\
\hline & More DO & 57 & 4,00 &, 756 & & & \\
\hline
\end{tabular}


Management, Vol. 25, 2020, No.1, pp. 193-213

S. Rocco, A. Selinšek: THE DIFFERENCE OF MANAGERIAL APPROACH ...

\begin{tabular}{|c|c|c|c|c|c|c|c|}
\hline \multirow{2}{*}{$\begin{array}{l}\text { Design improves our } \\
\text { internal and external } \\
\text { communication. }\end{array}$} & Less DO & 55 & 3,20 & ,951 & \multirow{2}{*}{$-7,199$} & \multirow{2}{*}{98} &, 000 \\
\hline & More DO & 57 & 4,33 & ,690 & & & \\
\hline \multirow{2}{*}{$\begin{array}{l}\text { Design improves our } \\
\text { services and working } \\
\text { processes. }\end{array}$} & Less DO & 55 & 3,22 & ,917 & \multirow{2}{*}{$-7,493$} & \multirow{2}{*}{110} &, 000 \\
\hline & More DO & 57 & 4,35 & ,668 & & & \\
\hline \multirow{2}{*}{$\begin{array}{l}\text { Design involves our } \\
\text { customers in a co- } \\
\text { creation process. }\end{array}$} & Less DO & 55 & 2,84 & ,996 & \multirow[b]{2}{*}{$-5,753$} & \multirow[b]{2}{*}{110} &, 000 \\
\hline & More DO & 57 & 3,93 & 1,015 & & & \\
\hline \multirow{2}{*}{$\begin{array}{l}\text { Design provides } \\
\text { sustainable development } \\
\text { and benefits to the } \\
\text { community. }\end{array}$} & Less DO & 55 & 2,85 &, 826 & \multirow{2}{*}{$-6,587$} & \multirow{2}{*}{110} &, 000 \\
\hline & More DO & 57 & 3,91 &, 872 & & & \\
\hline \multirow{2}{*}{$\begin{array}{l}\text { Design improves our } \\
\text { long-term goals / return- } \\
\text { on-investment. }\end{array}$} & Less DO & 55 & 3,05 &, 731 & \multirow{2}{*}{$-9,160$} & \multirow[b]{2}{*}{110} &, 000 \\
\hline & More DO & 57 & 4,30 &, 706 & & & \\
\hline
\end{tabular}

Source: Research results

Table 2 shows all the variables of perceived design value, for more and less DO companies, as seen from the managers' perspective. T- tests for independent samples show that in all design elements Sig. value was 0.000 or $p<0.01$ - which means that there is a statistically significant difference. Managers in companies which are more design oriented gave statistically significantly higher values to all elements of design from question $\mathrm{P} 9$ and their contribution to business success. The highest mean value by managers in more design-oriented companies was given for the statement that Design creates competitive advantage (4.81), and that Design allows a company to sell at a higher price (4.79), while Design contributes significantly to benefits perceived by consumers (4.63) is in the third place.

According to the results, it can be concluded that managers in more design-oriented companies have better perception of design and its contribution to business, and, therefore, hypothesis $\mathrm{H} 2$ has been confirmed.

\subsection{The final PLS structural equation model}

The PLS SEM model was constructed at the end of the analysis to check the first initial conceptual research model, as well as to confirm direct and indirect influences between different constructs with their factors (see Figure 3). 


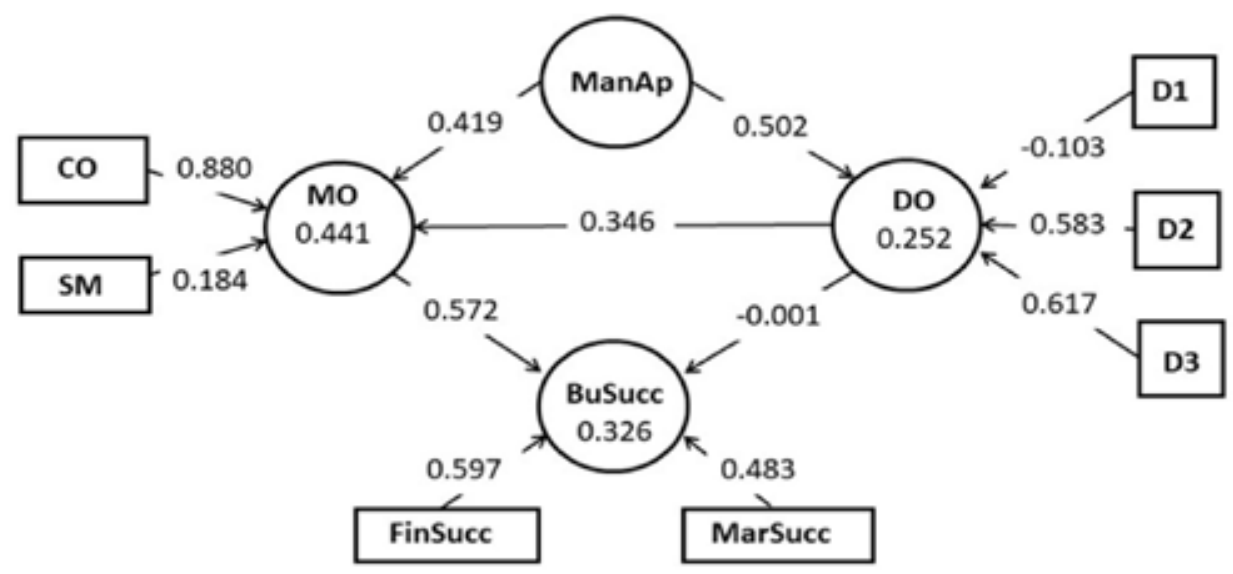

Figure 3. The final PLS SEM model with indicators of influence

Source: Research results

Note:

MARKET ORIENTATION (MO) factors: SM - Strategic Marketing; CO - Customer Orientation

DESIGN ORIENTATION (DO) factors: D1 - design as a competitive advantage; D2 - role of design; D3 - level of design (implementation)

MANAP - Managerial Approach

BUSUCC - Business Success; FinSucc - Financial Success; MarSucc - Market Success

As far as the indicators are concerned, there are three groups of indicators.

The proportion of variance of the latent variables, explained by the model, is indicated by the values in circles. These numbers show how much the variance of the latent variable is explained by other latent variables. Saturation coefficients of manifest variables - results show that DO is least saturated, i.e. determined, by variables of design as a competitive advantage and highly saturated by the other two dimensions of DO (the role of design and design levels). MO is highly saturated by customer orientation, while the strategic factor is less saturated by it. Business success is almost evenly saturated by the financial and market dimension of success. Path coefficients depend on the influence indicated by the arrows, as set in the model. The diagram shows that the influence of managerial approach is somewhat higher on DO (0.502) than on MO (0.419). The impact of DO on MO is significant (0.346) but lower than the previous two. Finally, there is a significant impact of MO on the company's success (see Table 3).

Table 3. The final PLS SEM model - direct and indirect impact between constructs

\begin{tabular}{l|l|l|l|l|l|l} 
Impact & $\begin{array}{l}\text { Direct } \\
\text { impact }\end{array}$ & Sig. & Indirect impact & Sig. & Total Impact & Sig. \\
\hline MANAP-DO* & 0,502 & $\mathrm{p}<0,01$ & - & - & 0,502 & $\mathrm{p}<0,01$ \\
\hline MANAP-MO & 0,419 & $\mathrm{p}<0,01$ & 0,174 & $\mathrm{p}<0,05$ & 0,593 & $\mathrm{p}<0,01$ \\
\hline
\end{tabular}


Management, Vol. 25, 2020, No.1, pp. 193-213

S. Rocco, A. Selinšek: THE DIFFERENCE OF MANAGERIAL APPROACH ...

\begin{tabular}{l|l|l|l|l|l|l}
\hline DO-MO & 0,346 & $\mathrm{p}<0,01$ & - & - & 0,346 & $\mathrm{p}<0,01$ \\
\hline DO-BSUC & $-0,001$ & n.s. & 0,198 & $\mathrm{p}<0,05$ & 0,197 & $\mathrm{p}<0,05$ \\
\hline MO-BSUC & 0,572 & $\mathrm{p}<0,01$ & - & - & 0,572 & $\mathrm{p}<0,01$ \\
\hline MANAP-BSUC & - & - & 0,338 & $\mathrm{p}<0,01$ & 0,338 & $\mathrm{p}<0,01$ \\
\hline
\end{tabular}

Source: Research results

Note: MANAP - Managerial Approach / DO - Design Orientation / MO - Market Orientation / BUSUCC - Business Success

Table 3 shows the values of direct and indirect impact of constructs. Managerial approach has a direct and significant influence on Design Orientation, as well as on Market Orientation, but it also influences Market Orientation and business results indirectly. Design Orientation has a direct and significant impact on Market Orientation, and it influences business results in the market indirectly, but significantly. Market Orientation has a direct and significant effect on business success.

\section{CONCLUSION}

The novelty of this paper is its focus on the DO-MO relationship, concerning the multiple dimensions of Design Orientation. Another contribution is the research on managerial approach toward Design Orientation. We examined the attitudes of managers and their influence on the exploitation of design resources. We made a comparison between managers' valuation of design in more DO companies with those in less DO companies. We found out that there are significant differences in their perception of design: the results confirm that managers in more design-oriented companies gave higher values to all elements of design, as well as to design's contribution to the success in the market, which indicates the strong influence of management on the choice of a company's design strategy.

The significant impact of managerial approach and its direct impact on business success confirm the previous researche, including those conducted in Croatia over the last 15 years, especially the ones focusing on the non-profits.

The study extends the existing knowledge of both direct and indirect influences of Design Orientation dimensions in relation to the Market Orientation. These results confirm that design resources are an important prerequisite for market success and are complementary to previous research (Borja de Mozota, 2003b; Design Council 2012; Moll et al., 2007; Kootstra, 2009; Venkatesh et al., 2012).

The novelty of our model is that design variables are introduced as intermediaries between Market Orientation, managerial approach and market performance, while previous studies have linked the Design Orientation of firms directly to financial success.

According to our results, the positive relationship of Design and Market Orientation is supported, noting that the intensity of influence of different Design Orientation dimensions varies.

Based on the final PLS model, which shows the impact of both major constructs and the interaction of their variables, managers could improve their management strategy. Design Orientation is linked strongly to the managerial approach, while its effect on Market Orientation 


\section{Journal of Contemporary Management Issues}

and business results is observed indirectly, through the orientation to customers. Further education of future managers in design disciplines and efficient design management could help to overcome the problem of understanding the design contribution to the company.

These findings are especially important for Croatia, where the structure of the economy shows that SMEs make up the majority of its economy. Therefore, managers in this segment should approach design as a resource strategically, in order to increase the competitiveness of their products and services. However, the problem is very complex in practice because of specific contexts - different industries, organizational structures, environments, and social aspects of design. All these influences should be taken into account before results can be generalized.

\section{LIMITATIONS AND RECOMMENDATIONS FOR FURTHER RESEARCH}

We should take into account some research limitations, while interpreting the results. The first limitation refers to the size of the sample - it was hard to motivate managers to complete a rather complex survey. Even though the pretesting was run before the final quantitative research, the proportion of respondents who dropped out, while completing the questionnaire was high. As a result, the final sample was not satisfactory. The main reason why a large number of respondents - managers and CEOs who lacked free time - did not complete the questionnaire is that it was quite long and the subject was complex, so it required a lot of time. A rather small sample could affect the reliability of the results adversely, so general conclusions should be drawn with caution. Also, although the databases were provided by reliable sources of several Croatian Institutions (Ministries and State Agencies), the sampling method was not based on probability theory, and could not provide a representative sample across all industries. Another limitation refers to the reliability of the responses. Our respondents were mostly executive managers or CEOs, who could be subjective in evaluating their own work and their company results. Therefore, responses may be overrated. Future research should, in addition to subjective measures of constructs, contain more objective data of external variables, such as valuing different industries, or impacts from the environment, to ensure a full insight into the complex bonds and different influences.

\section{REFERENCES}

1. Acklin, C; Fust, A. (2014). Towards a dynamic mode of design management and beyond, Proceedings, 19th DMI: Academic Design Management Conference Design Management in an Era of Disruption, London, 2-4 September

2. Atuahene-Gima, K. (1995). An exploratory analysis of the impact of market orientation on new product performance. Journal of Product Innovation Management, 12, 275-93

3. Barilović Z.; Leko Šimić, M.; Štimac H. (2014). Marketing orientation of educational institutions in the field of Project Management, Organization, Technology and Management in Construction, 6(1), 942 - 948

4. Bayazit, N. (2004). Investigating Design: A Review of Forty Years of Design Research, Design Issues, 20(1), 16-28 
5. Best K. (2006). Design Management: Managing Design Strategy, Process and Implementation, Ava Academia

6. Best K. (2010). The Fundamentals of Design Management, Ava Publishing

7. Beverland, M., Farrell, F. (2007). What does it mean to be design-led?, Design Management Review, 18(4): 10-17.

8. Bodlaj M. (2010). The Impact of a Responsive and Proactive Market Orientation on Innovation and Business Performance, Economic and Business Review, 12(4), 241-261

9. Borja de Mozota, B. (2003a). Design management: Using design to build brand value and corporate innovation. DMI/Allworth Press, New York.

10. Borja de Mozota, B. (2003b). Design and competitive edge: A model for design management excellence in European SMEs, Université Paris $\mathrm{X}$ Nanterre. Reprint \#02ABOR88, first published in Design Management Journal, 2, 88-103.

11. Borja de Mozota, B. (2009). Design management as core competency: From "Design You Can See" to "Design You Can't See". Journal of DMI, 4, 91-98.

12. Borja de Mozota, B. (2011). Design Economics - Microeconomics and Macroeconomics: exploring the value of designers' skills in our 21 st century economy. CUMULUS // DRS SIG on Design Pedagogy - 1st International Symposium for Design Education Researchers, Paris, 17-39.

13. Borja de Mozota, B., Peinado, A. D. (2013): New Aroaches to Theory and Research in Art \& Design lead Educational Programs - Can "Design Thinking" sparkle new answers to old problems?, CAA Conference, New York.
14. Božić, Lj.; Mohnen, P. (2016) Determinants of Innovation in Croatian SMEs - Comparison of Service and Manufacturing Firms, Tržište/Market, 28(1), 7-27

15. Božić, L.; Ozretić-Došen, Đ. (2015). Enabling innovation and creativity in market-oriented firms, Baltic Journal of Management, 10(2), 144-165.

16. Brown, T. (2008): Design Thinking, Harvard Business Review, June, 85-92

17. Buchanan, R. (2015). Worlds in the Making: Design, Management, and the Reform of Organizational Culture. The Journal of Design, Economics, and Innovation, 1(1), 5-21.

18. Centre for Design Innovation Ireland (2007). Design Difference - Design Innovation Research http://www. designinnovation.ie/downloads/ ResearchMethodology.pdf

19. Chiva, R., Alegre, J. (2009). Investment in Design and Firm Performance: The Mediating Role of Design Management, The Journal of Product Innovation Management, 26(4), 424-440

20. Coley, L. S., Mentzer, J. T., Coope, M. (2010). Is Consumer Orientation A Dimension of Market Orientation in Consumer Markets?, Journal of Market Theory and Practice, 18(2), 141-154

21. Cox G. (2005) The Cox Review of Creativity in Business: Building on the UK's Strengths. London: Design Council

22. Cooper, R., Press, M. (1995). The Design Agenda. Wiley

23. Design Council. (2004). Designing Britain 2005-2006. http://www.designcouncil.org.uk/factfinder

24. Design Council (2012), Design delivers for business. http://www.designcouncil. org.uk 
25. Design Council. (2015). Innovation by Design. How design enables science and technology research to achieve greater impact, DC, Available at: https://www.designcouncil.org.uk/ resources/report/innovation-design

26. Design Council (2018.) The Design Economy 2018. The State of Design in the UK, DC, available at: https:// www.designcouncil.org.uk/resources/ report/design-economy-2018, aroached 12052019

27. Design Management Institute - DMI (2015). Design Value Index Results and Commentary, https://www.dmi.org/ page/2015DVIandOTW

28. Dreyfuss, H. (1967). Designing for People. New York: Paragraphic Books.

29. Ekman K, Björklund T., Kirjavainen S., Laakso M. (Eds.) (2017). Passionbased Co-creation. Helsinki: Aalto Design Factory, Aalto University.

30. European Commission (2013). Implementing an Action Plan for Design Driven Innovation. EC Commission staff working document, $\operatorname{SWD}(2013)$ 380 final, Brussels

31. European Commission (2003). Commission recommendation of 6 May 2003 concerning the definition of SMEs, https://ec.europa.eu/growth/ smes/business-friendly-environment/ sme-definition_en

32. Gerlitz, L. (2016). Developing a Design Management Model for Innovating SMEs in the Context of Regional Smart Specialisation, Research in Economics and Business: Central and Eastern Europe, 8(2), 26-57

33. Gluić, J., Mihanović, Z. (2016). International Market Orientation and Stakeholder Management in Institutions of Culture and Art in Croatia, Management, 21(Special Issue), 105-130
34. Gorb, P. (1990). Design Management: Papers from the London Business School. Phaidon Press.

35. Grinstein, A. (2008) The relationships between market orientation and alternative strategic orientations: A meta-analysis, European Journal of Marketing, 42 (1/2), 115-134.

36. Gumesson, E. (1991). Marketing Orientation Revisited: The crucial role of the part-time marketer, European Journal of Marketing, 25 (2), 60-75

37. Henseler J., Ringle, C. M., Sarstedt, M. (2015). A new criterion for assessing discriminant validity in variance-based structural equation modeling, Journal of the Academy of Marketing Science, 43, 115-135.

38. Jaworski, B. J, Kohli, A. K. (1993). Market Orientation: Antecedents and consequences. Journal of Marketing, 57(3), 53-70.

39. Johansson, U., Svengren Holm, L. (2008). Patterns of interaction - A study of relations between designers, engineers, marketers and top management in four companies, International DMI Education Conference on Design Thinking: New challenges for designers, managers, and organizations, Paris, France.

40. Junginger, S. (2009). Parts and Wholes: Places of Design Thinking in Organizational Life, January 2009, Strategic Design Research Journal, 2(09), 23-29

41. Kelley T., Kelley D. (2013). Creative Confidence: Unleashing the Creative Potential Within Us All. New York: Crown Publishing.

42. Kohli, A., Jaworski, B., Kumar, A.(1993). MARKOR: A Measure of Market Orientation, Journal of Market Ressearch, 30 (4), 467-477. 
43. Kootstra, G. L. (2009). The Incorporation of Design Management in Today's Business Practices - An analysis of design management practices in Europe, DME Survey, Inholland.

44. Kotler, P., Rath, G. A. (1984). Design: A Powerful but Neglected Strategic Tool. Journal of Business Strategy, 5(2), 16-21.

45. Lafferty B. A., Hult G. T. M., (2001). A synthesis of contemporary market orientation perspectives, European Journal of Marketing, 35(1/2), 92-109.

46. Martin, R. (2009) The Design of Business: Why Design Thinking is the Next Competitive Advantage. Boston: Harvard Business Press Publishing.

47. Martin, J. H., Martin, B. A., Grbac, B. (1998). Employee Involvement And Market Orientation In A Transition Economy: Importance, Problems And A Solution, Journal of Managerial Issues, 10(4), 485-502

48. Martin J. H., Grbac, B. (2003). Using supply chain management to leverage a firm's market orientation, Industrial Marketing Management, 32(1), 25-38.

49. Miočević, D., Crnjak-Karanović, B. (2012). The Export Market Orientation-export performance relationship in emerging markets: The case of Croatian SME exporters, International Journal of Business and Emerging Markets, 4(2), 107-122.

50. Moll, I., Montana, J., Guzman, F., Praallada, F. S. (2007). Market orientation and design orientation: A management model. Journal of Marketing Management, 23(9): 861-876

51. Naiman, L. (2019). Design Thinking as a Strategy for Innovation, The European Business Review, June, https://www. europeanbusinessreview.com/designthinking-as-a-strategy-for-innovation/
52. Narver, J., Slater, S. (1990). The Effect of a Market Orientation on Business Profitability. Journal of Marketing, 54(4), 20-35.

53. Narver, J. C., Slater, F. S, MacLachlan, D. L. (2004). Responsive and proactive market orientation and new-product success. The Journal of Product Innovation Management, 21, 334-347.

54. Norman, D.A. (2004). Emotional Design. New York: Basic Books.

55. Pavičić, J., Alfirević, N., Mihanović Z. (2008). Market orientation in managing relationships with multiple constituencies of Croatian higher education, Higher Education, 57, 191-207.

56. Pisnik, A., Dlačić, J., Milfelner, B. (2016). The Importance of Perceived Service Value in Retail Banking Services, Tržište/Market, 28(2), 191-212.

57. Rae, J. (2013). What Is the Real Value of Design?, DMI Review, Winter, 30-37

58. Rau, C., Zbiek, A., Jonas, J. M. (2017). Creating Competitive Advantage from Services, Research-Technology Management, 60(3), 48-56.

59. Rocco, S., Pisnik, A. (2016a) The Conceptual Framework for Integrating Market and Design Orientation within Marketing, in: Vrankic, I.; Tomic, D. (Eds.), Book of Proceedings, 13th International Scientific Conference on Economic and Social Development, 515-525. Varazdin: VEDA.

60. Rocco S., Pisnik A. (2016b). Focusing On Customer: Relationships Between Design And Market Orientation, International Journal of Innovation and Economics Development, 2(4), 7-16, https://researchleap.com/wp-content/uploads/2016/11/Focusing-on-CustomerRelationships-between-Design-andMarket-Orientation.pdf 
61. Rocco, S.; Selinšek, A. (2019). The Structure of Design Orientation and its Relationship with Market Orientation, Naše gospodarstvo/Our Economy, 65(3), 50-62.

62. Slater F. S., Narver, J. C. (2000). The Positive Effect of a Market Orientation on Business Profitability: A Balanced Replication, Journal of Business Research 48, 69-73.

63. Snoj B., Milfelner B., Gabrijan V. (2007). An Examination of the Relationships among Market Orientation, Innovation Resources, Reputational Resources, and Company Performance in the Transitional Economy of Slovenia, Canadian Journal of Administrative Sciences, 24, 151-164.

64. Stevens, J, Moultrie, J., Crylli, N. (2008). Designing and Design Thinking in Strategy Concepts: Frameworks Towards an Intervention Tool, International DMI Education Conference, Design Thinking, ESSEC, Cergy-Pointoise.

65. Stuart F. I., Tax S. (2004). Toward an integrative aroach to designing service experiencesLessons learned from the theatre, Journal of Operations Management 22, 609-627.
66. Quartz + Co (2011). Making of International Design Policies and Strategies for Leading Design Schools and Research Institutions - Design 2020, Denmark.

67. Ulrich, K. T. and S. D. Einger (2003). Product Design and Development. New York: McGrawHill/Irwin.

68. Venkatesh A., Digerfeldt-Månsson T., Brunel F.F., Chen S. (2012 ). Design orientation: a grounded theory analysis of design thinking and action, Marketing Theory, 12(3), 289-309.

69. Veryzer, R.W., Borja de Mozota, B. (2005). The impact of user-oriented design on new product development: An examination of fundamentals relationship. Journal of Product Innovation Management, 22, 128-143.

70. Voola, R. \& O’Cass, A. (2010). Implementing competitive strategies: the role of responsive and proactive market orientations. European Journal of Marketing, 44 (1/2), 245-266.

71. Von Stamm, B. (2003). Managing Innovation, Design and Creativity. London: John Wiley \& Sons Ltd.

72. Yong A. G., Pearce S. (2013). A Beginner's Guide to Factor Analysis: Focusing on Exploratory Factor Analysis, Tutorials in Quantitative Methods for Psychology, 9(2), 79-94. 


\section{RAZLIKA MENADŽERSKOG PRISTUPA U PODUZEĆIMA VIŠE ILI MANJE ORIJENTIRANIMA PREMA DIZAJNU}

\begin{abstract}
Sažetak. Dokje marketinška orijentacija poduzeća detaljno analizirana, pregled marketinške literature pokazuje da postoji značajno manje istraživanja orijentacije prema dizajnu, a posebno nedostaje literature o njihovom međusobnom odnosu. U ovom se radu analiziraju varijable orijentacije prema dizajnu i marketingu, temeljem postojećih istraživanja te se razvija mjerni instrument za buduća istraživanja. Također se istražuje djelovanje menadžerskog pristupa na korištenje dizajnerskih resursa poduzeća. U radu se iznose dvije hipoteze: prva se odnosi na odnos između dizajnerske $i$ marketinške orijentacije, pri čemu se uzimaju u obzir razlicite dimenzije orijentacije prema dizajnu, dok se druga hipoteza odnosi na razlike $u$ menadžerskom pristupu, u poduzećima s većom, ili manjom orijentacijom prema dizajnu. $U$ prvoj, kvalitativnoj fazi istraživanja, evaluirali su se istraživački konstrukti $i$ varijable, dok se u drugoj, kvantitativnoj fazi istraživanja, koristila internetska anketa menadžera i predsjednika/ica uprava hrvatskih poduzeća. U našem završnom modelu, dimenzije dizajna predstavljaju posredničke varijable između marketinške orijentacije, menadžerskog pristupa i tržišnih
\end{abstract}

rezultata. Empirijski rezultati potvrđuju da se menadžeri, u poduzećima koja nisu orijentirana prema dizajnu, razlikuju od onih u poduzećima orijentiranim prema dizajnu, $s$ obzirom na percipiranu vrijednost dizajna. Svijest menadžera i predsjednika/ica uprava o dizajnu, njegovoj vrijednosti i potencijalu od velikog su značaja za implementaciju dizajna te orijentaciju poduzeća kao cjeline prema dizajnu, a što posebno dolazi do izražaja u malim i srednjim poduzećima. Prema dobivenim rezultatima, menadžerski pristup direktno utječe na orijentaciju prema dizajnu, ali $i$ na marketinšku orijentaciju te, kako direktno, tako $i$ indirektno, utječe $i$ na ostvarene poslovne rezultate. Rezultati ovog istraživanja mogu imati implikacije za istraživače, ali $i$ za menadžere u poslovnoj praksi, posebno u novim tržišnim gospodarstvima, u kojima orijentacija prema dizajnu nije dovoljno istražena. Buduća bi se istraživanja ove problematike trebala provesti i u drugim zemljama u regiji.

Ključne riječi: upravljanje dizajnom, orijentacija prema dizajnu, marketinška orijentacija, nova tržišna gospodarstva, menadžerski pristup 